\title{
PELAKSANAAN PERLINDUNGAN KONSUMEN DI INDONESIA
}

Oleh :

\author{
1. Dr. Niru Anita Sinaga, SH, MH \\ Dosen Tetap Fakultas Hukum \\ Universitas Suryadarma Jakarta. \\ Email : (anita_s1naga@yahoo.com)
}

\author{
2. Nunuk Sulisrudatin, SH, SIP, MSI. \\ Dosen Tetap Fakultas Hukum \\ Universitas Suryadarma Jakarta. \\ Email : (bununux@gmail.com)
}

\begin{abstract}
Abstrak:
Setiap orang baik sendiri maupun secara bersama-sama pasti menjadi konsumen untuk suatu produk barang atau jasa tertentu. Untuk itu dibutuhkan perlindungan hukum para pihak secara seimbang baik pada saat sebelum terjadinya transaksi dan/atau pada saat setelah terjadinya transaksi. Secara umum dikenal ada empat hak dasar konsumen yang harus dilindungi, yaitu: hak untuk mendapatkan keamanan, hak untuk mendapat informasi, hak untuk memilih dan hak untuk didengar.

Dalam prakteknya perlindungan hukum terhadap konsumen masih menimbulkan berbagai permasalahan yang dipengaruhi berbagai faktor, antara lain: yang berkaitan dengan struktur hukum, substansi hukum, budaya hukum dan aparatur birokrasi.

Untuk mengatasi permasalahan-permasalah tersebut, maka perlu dicarikan solusi, antara lain: Sesegera mungkin melakukan revisi terhadap UUPK yang ada; hukum yang akan dibentuk adalah hukum yang responsif; dan keseriusan penegak hukum dalam mengawasi, memproses dan menyelesaikan setiap pelanggaran yang terjadi dengan memberikan hukuman/sanksi yang tegas dan setimpal agar menimbulkan efek jera bagi yang melakukan pelanggaran.
\end{abstract}

\begin{abstract}
Everyone either alone or jointly surely be the consumers to a particular product or service. That requires the legal protection of the parties in a balanced manner both at the time prior to the transaction and/or at the time after the transaction. Generally known there are four basic consumer rights that must be protected, namely: the right to safety, the right to information, right to vote and the right to be heard. In practice the legal protection of consumers still poses various problems that affected various factors, among others: relating to the legal structure, the substantive law and legal culture and bureaucratic apparatus.

For addressing these problems, it is necessary to look for solutions, among others: As soon as possible to revise the existing UUPK; law to be formed is responsive law; and the seriousness of law enforcement to monitor, process and resolve any violations with penalties/sanctions were firm and commensurate so deterrent to those who commit violations
\end{abstract}




\section{[PENDAHULUAN]}

Hukum perlindungan konsumen dewasa ini mendapat cukup perhatian, karena menyangkut aturan-aturan guna mensejahterakan masyarakat, bukan saja masyarakat selaku konsumen yang mendapat perlindungan, namun pelaku usaha juga mempunyai hak yang sama untuk mendapat perlindungan, masingmasing ada hak dan kewajibannya. Pemerintah berperan mengatur, mengawasi, dan mengontrol, sehingga tercipta sistem yang kondusif saling berkaitan satu dengan lain dengan demikian tujuan mensejahterakan masyarakat secara luas dapat tercapai. ${ }^{1}$

Perlindungan terhadap konsumen dipandang secara material maupun formal makin terasa sangat penting, mengingat makin lajunya ilmu pengetahuan dan teknologi yang merupakan motor penggerak bagi produktivitas dan efisiensi produsen atas barang atau jasa yang dihasilkan dalam rangka mencapai sasaran usaha. Dalam rangka mengejar dan mencapai kedua hal tersebut, akhirnya baik langsung atau tidak langsung, konsumenlah yang pada akhirnya merasakan dampaknya. Dengan demikian, upaya-upaya untuk memberikan perlindungan yang memadai terhadap kepentingan konsumen merupakan suatu hal yang penting dan mendesak untuk segera dicari solusinya, terutama di Indonesia mengingat sedemikian kompleksnya permasalahan yang menyangkut perlindungan konsumen, lebih-lebih menyongsong era perdagangan bebas yang akan datang. ${ }^{2}$

Konsumen yang keberadaannya sangat tidak terbatas dengan strata yang sangat

${ }^{1}$ Celina Tri Siwi Kristiyanti, Hukum Perlindungan Konsumen, Jakarta: Sinar Grafika, 2008, hal.1.

${ }^{2}$ Ibid, hal. 5. bervariasi menyebabkan produsen melakukan kegiatan pemasaran dan distribusi produk barang atau jasa dengan cara seefektif mungkin agar dapat mencapai konsumen yang sangat majemuk tersebut. Untuk itu semua cara pendekatan diupayakan sehingga mungkin menimbulkan berbagai dampak, termasuk keadaan yang menjurus pada tindakan yang bersifat negative bahkan tidak terpuji yang berawal dari itikad buruk. Dampak buruk yang lain terjadi antara lain menyangkut kualitas atau mutu barang, informasi yang tidak jelas bahkan menyesatkan, pemalsuan dan sebagainya. ${ }^{3}$

Pada situasi ekonomi global dan menuju era perdagangan bebas, upaya mempertahankan pelanggan/konsumen merupakan dambaan bagi setiap produsen, mengingat makin ketatnya persaingan untuk berusaha. Persaingan yang makin ketat juga memberikan dampak negative terhadap konsumen pada umumnya. Sasaran setiap negara dan pengusaha saat ini adalah menuju pemasaran global. Pada dasarnya dapat mengubah berbagai konsep atau cara pandang dan cara pendekatan mengenai banyak hal atau strategi pemasaran, hal ini mempengaruhi juga perlindungan konsumen secara global. Perlindungan konsumen dalam era globalisasi menjadi sangat penting terhadap haknya yang bersifat universal dan yang bersifat sangat spesifik.

Era perdagangan bebas merupakan suatu era kemana pemasaran merupakan suatau disiplin universal. Konsep-konsep pemasaran dipandang dari strategi pemasaran global telah berubah dari waktu

\footnotetext{
${ }^{3}$ Sri Redjeki Hartono, makalah Aspek-aspek Hukum Perlindungan Konsumen dalam buku Hukum Perlindungan Konsumen, Ibid, hal. 34, dalam buku Celina Tri Siwi Kristiyanti, Hukum Perlindungan Konsumen, Jakarta: Sinar Grafika, 2008, hal.6.
} 
kewaktu, sebagaimana tahapan berikut: ${ }^{4}$ Pertama, konsep pemasaran pada awalnya adalah memfokuskan pada produk yang lebih baik yang berdasarkan pada standard dan nilai internal. Hal ini dilakukan dengan tujuan memperoleh laba, dengan menjual atau membujuk pelanggan potensial untuk menukar uangnya dengan produk perusahan. Kedua, pada decade enam puluhan focus pemasaran dari produk kepada pelanggan. Sasaran masih tetap pada laba, tetapi cara pencapaian menjadi luas, yaitu dengan pembaharuan pemasaran marketing mix atau 4P (Product, Price, Promotion, And Place) Produk, Harga, Promosi, dan Saluran distribusi. Ketiga, sebagai konsep baru pemasaran dengan pembaharuan dari konsep pemasaran menjadi konsep strategi. Konsep strategi pemasaran pada dasarnya mengubah focus pemasaran dari pelanggan atau produk kepada pelanggan dalam konteks lingkungan eksternal yang lebih luas. Untuk itu harus memanfaatkan pelanggan yang ada termasuk pesaing, kebijakan yang berlaku, peraturan pemerintah serta kekuatan makro, ekonomi, social, politik secara luas.

Bertolak dari rangkain perubahan konsep pemasaran tersebut, perlindungan terhadap konsumen juga membutuhkan pemikiran yang luas pula. Pemikiran konsep secara luas dan kajian dari aspek hukum pun juga membutuhkan wawasan hukum yang luas, sehingga tidaklah dapat dikaji dari suatu aspek hukum semata-mata. Hal ini sangat penting mengingat kepentingan konsumen pada dasarnya sudah ada sejak awal sebelum barang/jasa diproduksi selama dalam produksi sampai pada saat distribus sehingga sampai ditangan konsumen untuk dimanfaatkan secara maksimal. ${ }^{5}$

${ }^{4}$ Ibid, hal. 34-35.

${ }^{5}$ Celina Tri Siwi Kristiyanti, Op.Cit., hal. 7.
Organisasi dunia seperti PBB pun tidak kurang perhatiannya terhadap masalah Perlindungan Konsumen, Hal ini terbukti dengan dikeluarkannya Resolusi PBB No. 39/248 Tahun 1985. Dalam resolusi ini kepentingan konsumen yang harus dilindungi meliputi: ${ }^{6}$

a. perlindungan konsumen dari bahayabahaya terhadap kesehatan dan keamanannya

b. promosi dan perlindungan kepentingan sosial ekonomi konsumen

c. tersedianya informasi yang memadai bagi konsumen untuk memberikan kemampuan mereka dalam melakukan pilihan yang tepat sesuai dengan kehendak dan kebutuhan pribadi

d. pendidikan konsumen

e. tersedianya upaya ganti rugi yang efektif

f. kebebasan untuk membentuk organisasi konsumen

Tidak terkecuali Indonesia juga berusaha untuk memberikan perlindungan konsumen dengan cara, salah satu diantaranya yaitu membentuk Undangundang No. 8 Tahun 1999 tentang Perlindungan Konsumen( selanjutnya disingkat UUPK) Perlindungan konsumen di Indonesia sangat penting dapat dilihat pada UUPK bagian menimbang, antara lain: bahwa pembangunan nasional bertujuan untuk mewujudkan suatu masyarakat adil dan makmur yang merata materiil dan spiritual dalam era demokrasi ekonomi berdasarkan Pancasila dan Undang-undang Dasar 1945; bahwa pembangunan perekonomian nasional

6 Erman Rajagukguk, makalah Pentingnya Perlindungan Konsumen Dalam Era Perdagangan Bebas dalam buku Hukum Perlindungan Konsumen, penyunting Husni Syawali dan Neni Sri Imaniyati, Bandung: Mandar Madju, 2000, hal. 3, dalam buku Celina Tri Siwi Kristiyanti, Hukum Perlindungan Konsumen, Jakarta: Sinar Grafika, 2008, hal.3. 


pada era globalisasi harus dapat lain. Globalisasi menyebabkan

mendukung tumbuhnya dunia usaha sehingga mampu menghasilkan beraneka barang dan/jasa yang memiliki kandungan teknologi yang dapat meningkatkan kesejahteraan masyarakat banyak dan sekaligus mendapatkan kepastian atas barang dan / jasa yang diperoleh dari perdagangan tanpa mengakibatkan kerugian konsumen; bahwa semakin terbukanya pasar nasional sebagai akibat dari proses globalisasi ekonomi harus tetap menjamin peningkatan kesejahteraan masyarakat serta kepastian atas mutu, jumlah dan keamanan barang dan/atau jasa yang diperolehnya di pasar; bahwa untuk meningkatkan harkat dan martabat konsumen perlu meningkatkan kesadaran, pengetahuan, kepedulian, kemampuan dan kemandirian konsumen untuk melindungi dirinya serta menumbuhkembangkan sikap perilaku usaha yang bertanggung jawab; bahwa ketentuan hukum yang melindungi kepentingan konsumen di Indonesia belum memadai diperlukan perangkat peraturan perundang-undangan untuk mewujudkan keseimbangan perlindungan kepentingan konsumen dan pelaku usaha sehingga tercipta perekonomian yang sehat ${ }^{7}$

Perlindungan konsumen harus mendapat perlindungan yang lebih, karena investasi asing telah menjadi bagian pembangunan ekonomi Indonesia, dimana ekonomi Indonesia juga telah berkait dengan ekonomi dunia. Persaingan perdagangan internasional dapat membawa implikasi negative bagi perlindungan konsumen. Kini transaksi menjadi beraneka ragam dan rumit, seperti kontrak pembuatan barang, waralaba, imbal beli, turnkey project, alih teknologi, aliansi strategis internasional, aktivitas finansial, dan lain-

7 Undang-undang No.8 Tahun 1999 Tentang Perlindungan Konsumen bagian Menimbang berkembangnya saling ketergantungan pelaku ekonomi dunia. Manufaktur, perdagangan, investasi melewati batasbatas negara, meningkatkan intensitas persaingan. Gejala ini dipercepat oleh kemajuan komunikasi dan transportasi teknologi. ${ }^{8}$

Globalisasi adalah gerakan perluasan pasar, dan di semua pasar yang berdasarkan persaingan, selalu ada yang kalah dan yang menang. Perdagangan bebas juga menambah kesenjangan antara negara maju dan negara pinggiran (periphery), yang akan membawa akibat pada komposisi masyarakat dan kondisi kehidupan mereka. Tiadanya perlindungan konsumen adalah sebagian dari gejala negeri yang kalah dalam perdagangan bebas. ${ }^{9}$

Setiap orang pada suatu waktu dalam posisi tunggal / sendiri maupun berkelompok bersama orang lain, dalam keadaan apapun pasti menjadi konsumen untuk suatu produk barang atau jasa tertentu. Keadaan yang universal ini pada beberapa sisi menunjukkan adanya berbagai kelemahan pada konsumen sehingga membutuhkan perlindungan hukum yang sifatnya universal. Mengingat lemahnya perlindungan konsumen pada umumnya dibandingkan dengan kedudukan produsen yang relative lebih kuat dalam banyak hal, maka pembahasan perlindungan konsumen akan selalu terasa actual dan selalu penting untuk dikaji ulang. ${ }^{10}$

\footnotetext{
${ }^{8}$ Celina Tri Siwi Kristiyanti, Op.Cit., hal. 4-5.

${ }^{9}$ Jaqnes Delors, The Future of Free Trade in Europe and The Word, Fordham International Law Journal Vol 18 (1995), hal.723 dan makalah Erman Rajagukguk, Ibid, hal. 4, dalam buku Celina Tri Siwi Kristiyanti, Hukum Perlindungan Konsumen, Jakarta: Sinar Grafika, 2008, hal.5.

${ }^{10}$ Celina Tri Siwi Kristiyanti, Op.Cit., hal. 5.
} 
Dalam pelaksanaannya perlindungan konsumen ini di Indonesia masih banyak menimbulkan permasalahan

permasalahan, Permasalahan tersebut dipengaruhi berbagai faktor, antara lain: yang berkaitan dengan struktur hukum, substansi hukum, budaya hukum dan aparatur birokrasi. Secara garis besar kendala atau hambatan yang dihadapi dalam pelaksanaan UUPK adalah: karena tingkat kesadaran konsumen akan haknya masih rendah; rendahnya pendidikan konsumen; belum ada pihak yang menyentuh bagaimana mempersiapkan konsumen Indonesia menghadapi pasar bebas; masih lemahnya pengawasan dibidang standardisasi mutu barang; lemahnya produk perundang-undangan; persepsi pelaku usaha yang keliru dengan perlindungan konsumen akan menimbulkan kerugian.

Untuk mengatasi permasalahanpermasalah tersebut, maka perlu dicarikan solusi, antara lain prasyarat-prasyarat apa yang harus dipenuhi agar era perdagangan bebas bagi konsumen di Indonesia menjadi anugerah, justru bukan sebaliknya menjadi musibah. Dalam melakukan perdagangan harus dipegang prisip bahwa produsen dan konsumen sama-sama membutuhkan, dan saling ketergantungan satu sama lain baik dalam waktu yang singkat maupun waktu yang lama. Sehingga hubungan yang terus menerus dan berkesinambungan sepanjang masa harus sama-sama dijaga. Hubungan antara produsen dan konsumen yang berkelanjutan terjadi saat proses produksi, distribusi pada pemasaran dan penawaran. Rangkaian perbuatan tersebut merupakan perbuatan hukum yang mempunyai akibat hukum terhadap semua pihak, atau pihakpihak tertentu. Untuk itu perlu diatur perlindungan konsumen berdasarkan undang-undang menyangkut, antara lain:
Mutu barang, cara prosedur produksi, syarat kesehatan, syarat pengemasan, syarat lingkungan, dan sebagainya. Sehingga tujuan dari hukum perlindungan konsumen dapat tercapai, yaitu: secara langsung dapat meningkatkan martabat dan kesadaran konsumen, dan secara tidak langsung, hukum ini juga akan mendorong produsen untuk melakukan usaha dengan penuh tanggung jawab. Semua tujuan tersebut tentu dapat tercapai apabila hukum perlindungan konsumen dapat diterapkan secara konsekuen. Untuk mewujudkannya harapan tersebut, antara lain: ${ }^{11}$

1. Hukum perlindungan konsumen harus adil bagi konsumen maupun produsen, jadi tidak hanya membebani produsen dengan tanggung jawab, tetapi juga melindungi hak-haknya untuk melakukan usaha dengan jujur.

2. Aparat pelaksana hukumnya harus dibekali dengan sarana yang memadai dan disertai dengan tanggung jawab.

3. Penigkatan kesadaran konsumen akan hak-haknya.

4. Mengubah system nilai dalam masyarakat kearah sikap tindak yang mendukung pelaksanaan perlindungan konsumen.

Dipenuhinya persyaratan-persyaratan diatas diharapkan akan dapat mengangkat harkat dan martabat konsumen, sehingga mereka juga dapat diakui sebagai salah satu subjek dalam system perekonomian nasional disamping BUMN, Koperasi dan usaha swasta.

\section{PERMASALAHAN}

Dari latar belakang diatas dirumuskan 2 permasalahan sebagai berikut:

\footnotetext{
${ }^{11}$ Ibid, hal. 10-11.
} 
1. Mengapa perlindungan hukum terhadap konsumen di Indonesia sangat dibutuhkan?

2. Faktor - faktor apa saja yang menjadi kendala/hambatan dalam pelaksanaan Undang-undang No. 8 Tahun 1999 tentang Perlindungan Konsumen?

\section{PEMBAHASAN}

\section{Tinjauan Umum Tentang Perlindungan Konsumen di Indonesia}

Pengertian dan istilah dalam perlindungan konsumen

Istilah konsumen berasal dari bahasa Belanda: Konsument. Para ahli hukum pada umumnya sepakat bahwa arti konsumen adalah: "Pemakai akhir dari benda dan jasa (Uiteindelijke Gebruiker van Goerderen en Diensten) yang diserahkan kepada mereka oleh pengusaha

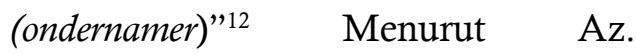
Nasution, pengertian konsumen adalah "Setiap orang yang mendapatkan secara sah dan menggunakan barang atau jasa untuk suatu kegunaan tertentu". ${ }^{13}$

Menurut Pasal 1 angka (2) UUPK menyebutkan bahwa "Konsumen adalah setiap orang pemakai barang dan/atau jasa yang tersedia dalam masyarakat, baik bagi kepentingan diri sendiri, keluarga, orang lain, maupun mahluk hidup lain dan tidak diperdagangkan".

12 Mariam Darus Badrulzaman, Perlindungan Terhadap Konsumen Dilihat Dari Sudut Perjanjian Baku (Standar), dalam BPHN, Simposium Aspek-Aspek Hukum Perlindungan Konsumen, Bandung: Binacipta, 1986, hal. 57.

13 Az.Nasution, Konsumen dan Hukum, Jakarta: Pustaka Sinar Harapan, 1995, hal. 69.
Pelaku usaha secara umum adalah orang atau badan hukum yang menghasilkan barang-barang dan/atau jasa dengan memproduksi barang dan/atau jasa tersebut untuk memenuhi kebutuhan masyarakat atau konsumen dengan mencari keuntungan dari barang-barang dan/atau jasa tersebut. Undangundang perlindungan konsumen (UUPK) tampaknya berusaha menghindari penggunaan kata "produsen" sebagai lawan dari kata "konsumen". Sehingga digunakan kata "pelaku usaha" yang mempunyai makna lebih luas, dimana istilah pelaku usaha ini dapat berarti juga kreditur (penyedia dana), produsen, penyalur, penjual dan terminologi lain yang lazim diberikan. ${ }^{14}$

Menurut pasal 1 angka (3) UUPK, yang dimaksud pelaku usaha adalah "Setiap orang perseorangan atau badan usaha, baik yang berbentuk badan hukum maupun bukan badan hukum yang didirikan dan berkedudukan atau melakukan kegiatan dalam wilayah hukum negara Republik Indonesia, baik sendiri maupun bersama-sama melalui perjanjian menyelenggarakan kegiatan usaha dalam berbagai bidang ekonomi". ${ }^{15}$ Dengan demikian dapat ditarik kesimpulan suatu pengertian yang dimaksud pelaku usaha adalah seperti yang dimaksud dalam pasal 1 angka (3) UUPK, yaitu setiap orang perseorangan atau badan usaha, baik yang berbentuk badan hukum maupun bukan badan hukum yang didirikan dan berkedudukan atau

\footnotetext{
${ }^{14}$ Shidarta, Hukum Perlindungan Konsumen, Jakarta: PT Grasindo, 2000, hal. 5.

${ }^{15}$ Undang-undang No.8 Tahun 1999, Op.Cit., Pasal 1 angka 3
} 
melakukan kegiatan dalam wilayah hukum negara Republik Indonesia, baik sendiri maupun bersama-sama melalui perjanjian menyelenggarakan kegiatan usaha dalam berbagai bidang ekonomi. Sedangkan Konsumen adalah setiap orang pemakai barang dan/atau jasa yang tersedia dalam masyarakat, baik bagi kepentingan diri sendiri, keluarga, orang lain maupun makhlukhidup lain dan tidak untuk diperdagangkan.

Perlindungan konsumen adalah segala upaya yang menjamin adanya kepastian hukum untuk memberi perlindungan kepada konsumen berdasarkan asas-asas yang terdapat pada perlindungan konsumen

Pasal 2 UUPK menyebutkan "perlindungan konsumen berasaskan manfaat, keadilan, serta keseimbangan, keamanan dan keselamatan konsumen serta kepastian hukum". Di dalam penjelasan pasal 2 UUPK menyebutkan perlindungan konsumen diselenggarakan sebagai usaha bersama berdasarkan 5 (lima) asas yang relevan dalam pembagunan nasional, yaitu: ${ }^{16}$

1. Asas manfaat dimaksudkan untuk mengamanatkan bahwa segala upaya dalam penyelenggaraan perlindungan konsumen harus memberi manfaat sebesarbesarnya bagi kepentingan konsumen dan pelaku usaha secra keseluruhan.

2. Asas keadilan dimaksudkan agar partisipasi seluruh rakyat dapat diwujudkan secara maksimal dan memberikan kesempatan kepeda konsumen dan pelaku usaha untuk memperoleh haknya dan melaksanakan kewajibannya secara adil.

3. Keseimbangan dimaksudkan untuk memberikan keseimbangan antar kepentingan konsumen, pelaku usaha, dan pemerintah dalam arti materiil maupun spirituil.

4. Asas keamanan dan keselamatan konsumen dimaksudkan untuk memberikan jaminan atas kesamanan dan keselamatan kepada konsumen dalam penggunaan, pemakaian, dan pemanfaatan barang dan/atau jasa yang dikonsumsi atau digunakan.

5. Asas kepastian hukum dimaksudkan agar baik pelaku usaha maupun konsumen menaati hukum dan memperoleh keadilan dalam penyelenggaraan perlindungan konsumen, serta negara menjamin kepastian hukum.

\section{Hak dan kewajiban konsumen}

Hak-hak konsumen yang ada dan diakui sekarang bermula dari perkembangan hak- hak konsumen yang ditegaskan dalam resolusi PBB Nomor 39/248 Tahun 1985 tentang perlindungan konsumen dan di Indonesia direalisasikan dalam UUPK. Resolusi Perserikatan Bangsa-Bangsa (PBB) Nomor 39/248 Tahun 1985 tentang Perlindungan Konsumen (Guidelines for Consumer Protection) juga merumuskan berbagai

${ }^{16}$ Ibid, bagian Penjelasan Pasal 2. 
kepentingan konsumen yang perlu dilindungi, yang meliputi: ${ }^{17}$

1. perlindungan konsumen dari bahaya-bahaya terhadap kesehatan dan keamananya;

2. promosi dan perlindungan kepentingan ekonomi sosial konsumen;

3. tersedianya informasi yang memadai bagi konsumen untuk memberikan kemampuan mereka melakukan pilihan yang tepat sesuai kehendak dan kebutuhan pribadi;

4. pendidikan konsumen;

5. tersedianya upaya ganti rugi yang efektif;

6. kebebasan untuk membentuk organisasi konsumen atau organisasi lainnya yang relevan dan memberikan kesempatan kepada organisasi tersebut untuk menyuarakan pendapatnya dalam proses pengambilan keputusan yang menyangkut kepentingan mereka.

Secara umum dikenal ada empat hak dasar konsumen, yaitu: hak untuk mendapatkan keamanan (the right to safety), hak untuk mendapat informasi (the right to be informed), hak untuk memilih (the right to choose) dan akhirnya hak untuk didengar (the right to be heard). ${ }^{18}$

Hak-hak konsumen yang harus dilindungi menurut Zoemrotin K.Susilo, yaitu: ${ }^{19}$ hak untuk

17 Gunawan Widjaja dan Ahmad Yani, Hukum tentang Perlindungan Konsumen, Jakara: PT Gramedia Pustaka Utama, 2001, hal. 27-28.

${ }^{18}$ Shidarta,Op.Cit., hal.16.

${ }^{19}$ Zoemrotin K.Susilo, Penyambung Lidah Konsumen, Jakarta: Puspa Swara, 1996, hal. 4. mendapatkan keamanan dan keselamatan; hak untuk memperoleh informasi yang benar dan jujur; hak untuk memilih barang/jasa yang dibutuhkan; hak untuk didengar pendapatnya; hak untuk mendapat ganti rugi; hak untuk mendapatkan lingkungan yang bersih dan sehat.

Sedangkan hak konsumen yang harus dilindungi berdasarkan UUPK adalah: ${ }^{20}$

a. hak atas kenyamanan, keamanan, dan keselamatan dalam mengkonsumsi barang dan/atau jasa;

b. hak untuk memilih barang dan/atau jasa serta mendapatkan barang dan/atau jasa tersebut sesuai dengan nilai tukar dan kondisi serta jaminan yang dijanjikan;

c. hak atas informasi yang benar, jelas, dan jujur mengenai kondisi dan jaminan barang dan/atau jasa;

d. hak untuk didengar pendapat dan keluhannya atas barang dan/atau jasa yang digunakan;

e. hak untuk mendapatkan advokasi, perlindungan, dan upaya penyelesaian sengketa perlindungan konsumen secara patut;

f. hak untuk mendapat pembinaan dan pendidikan konsumen;

g. hak unduk diperlakukan atau dilayani secara benar dan jujur serta tidak diskriminatif;

h. hak untuk mendapatkan kompensasi, ganti rugi dan/atau penggantian, apabila barang dan/atau jasa yang diterima tidak

${ }^{20}$ Undang-undang No.8 Tahun 1999, Op.Cit., Pasal 4. 
sesuai dengan perjanjian atau tidak sebagaimana mestinya;

i. hak - hak yang diatur dalam ketentuan peraturan perundangundangan lainnya.

\section{Kewajiban konsumen adalah: ${ }^{21}$}

a. membaca atau mengikuti petunjuk informasi dan prosedur pemakaian atau pemanfaatan barang dan/atau jasa, demi keamanan dan keselamatan;

b. beritikad baik dalam melakukan transaksi pembelian barang dan/atau jasa;

c. membayar sesuai dengan nilai tukar yang disepakati;

d. mengikuti upaya penyelesaian hukum sengketa perlindungan konsumen secara patut.

Hak pelaku usaha adalah $:^{22}$

a. hak untuk menerima pembayaran yang sesuai dengan kesepakatan mengenai kondisi dan nilai tukar barang dan/atau jasa yang diperdagangkan;

b. hak untuk mendapat perlindungan hukum dari tindakan konsumen yang beritikad tidak baik;

c. hak untuk melakukan pembelaan diri sepatutnya di dalam penyelesaian hukum sengketa konsumen;

d. hak untuk rehabilitasi nama baik apabila terbukti secara hukum bahwa kerugian konsumen tidak diakibatkan oleh barang dan/atau jasa yang diperdagangkan;

e. hak - hak yang diatur dalam ketentuan peraturan perundangundangan lainnya.
Kewajiban pelaku usaha adalah $:^{23}$

a. beritikad baik dalam melakukan kegiatan usahanya;

b. memberikan informasi yang benar, jelas dan jujur mengenai kondisi dan jaminan barang dan/atau jasa serta memberi penjelasan penggunaan, perbaikan dan pemeliharaan;

c. memperlakukan atau melayani konsumen secara benar dan jujur serta tidak diskriminatif;

d. menjamin mutu barang dan/atau jasa yang diproduksi dan/atau diperdagangkan berdasarkan ketentuan standar mutu barang dan/atau jasa yang berlaku;

e. memberi kesempatan kepada konsumen untuk menguji, dan/atau mencoba barang dan/atau jasa tertentu serta memberi jaminan dan/atau garansi atas barang yang dibuat dan/atau yang diperdagangkan;

f. memberi kompensasi, ganti rugi dan/atau penggantian atas kerugian akibat penggunaan, pemakaian dan pemanfaatan barang dan/atau jasa yang diperdagangkan;

g. memberi kompensasi, ganti rugi dan/atau penggantian apabila barang dan/atau jasa yang diterima atau dimanfaatkan tidak sesuai dengan perjanjian.

\section{Perbuatan yang dilarang berdasarkan UUPK}

Secara umum perbuatan yang dilarang bagi para pelaku usaha diatur dalam Bab IV UUPK yang terdiri dari 10

${ }^{21}$ Ibid, Pasal 5.

${ }^{23}$ Ibid, Pasal 7.

${ }^{22}$ Ibid, Pasal 6. 
pasal, dimulai dari pasal 8 sampai dengan 17. Ketentuan Pasal 8 UUPK merupakan satu-satunya ketentuan yang general bagi kegiatan usaha dari para pelaku usaha pabrikan dan distributor di Indonesia. Larangan tersebut meliputi kegiatan usaha untuk melaksanakan kegiatan produksi dan/atau perdagangan barang dan jasa yang :

a. tidak memenuhi atau tidak sesuai dengan standar yang dipersyaratkan dan ketentuan peraturan perundang-undangan.

b. tidak sesuia dengan berat bersih, isi bersih atau netto dan jumlah dalam hitungan sebagaimana yang dinyatakan dalam label atau etiket barang tersebut;

c. tidak sesuai dengan ukuran, takaran, timbangan dan jumlah dalam hitungan menurut ukuran yang sebenarnya;

d. tidak sesuai dengan kondisi, jaminan, keistimewaan atau kemanjuran sebagaimana dinyatakan dalam label, etiket atau keterangan barang dan/atau jasa tersebut;

e. tidak sesuai dengan mutu, tingkatan, komposisi, proses pengolahan, gaya mode, atau penggunaan tertentu sebagaimana dinyatakan dalam label atau keterangan barang dan/atau jasa tersebut;

f. tidak sesuai dengan janji yang dinyatakan dalam label, etiket, keterangan, iklan atau promosi penjualan barang dan/atau jasa tersebut;

g. tidak mencantumkan tanggal kadaluwarsa atau jangka waktu penggunaan/pemanfaatan yang paling baik atas barang tersebut; h. tidak mengikuti ketentuan berproduksi secara hala, sebagaimana pernyataan "halal" yang dicantumkan dalam label;

i. tidak memasang label atau membuat penjelasan barang yang memuat nama barang, ukuran, berat/isi bersih atau netto, komposisi, aturan pakai, tanggal pembuatan, akibat sampingan, nama dan alamat pelaku usaha serta keterangan lain untuk penggunaan yang menyurut ketentuan harus dipasang/dibuat;

j. tidak mencantumkan informasi dan/atau petunjuk penggunaan barang dalam bahasa Indonesia sesuai dengan ketentuan yang berlaku.

Secara garis besar larangan yang dikenakan dalam Pasal 8 UUPK tersebut dapat dibagi ke dalam dua larangan pokok yaitu $:^{24}$

1. larangan mengenai produk itu sendiri, yang tidak memenuhi syarat atau standar yang layak untuk dipergunakan atau dipakai atau dimanfaatkan oleh konsumen;

2. larangan mengenai ketersediaan informasi yang tidak benar dan tidak akurat yang menyesatkan konsumen.

Apabila pelaku usaha dalam menjalankan usahanya melanggar larangan - larangan dan/atau menimbulkan kerusakan, pencemaran dan/atau kerugian kepada konsumen akibat mengkonsumsi barang dan/atau jasa yang diperjual belikan

${ }^{24}$ Gunawan Widjaja dan Ahmad Yani, Op.Cit., hal. 39. 
maka pelaku usaha tersebut bertanggung jawab memberikan ganti rugi. Ganti rugi tersebut dapat berupa pengembalian uang atau penggantian barang dan/atau jasa sejenis atau setara nilainya atau perawatan kesehatan dan/atau pemberian santunan sesuai dengan ketentuan peraturan perundang-undangan yang berlaku. Pemberian ganti rugi dilaksanakan dalam tenggang waktu 7 (tujuh) hari setelah tanggal transaksi ${ }^{25}$. Disamping itu pelaku usaha periklanan juga bertanggung jawab atas iklan yang diproduksi dan segala akibat yang ditimbulkan oleh iklan tersebut. ${ }^{26}$

Namun dalam Pasal 27 UUPK disebutkan bahwa pelaku usaha yang memproduksi barang dibebaskan dari tanggung jawab atas kerugian yang diderita konsumen, apabila $:^{27}$

a. barang tersebut terbukti seharusnya tidak diedarkan atau dimaksudkan untuk diedarkan;

b. cacat barang timbul pada kemudian hari;

c. cacat timbul akibat tidak ditaatinya ketentuan mengenai kualifikasi barang;

d. kelalaian yang diakibatkan oleh konsumen;

e. lewatnya jangka waktu penuntutan 4 (empat) tahun sejak barang dibeli atau lewatnya jangka waktu yang diperjanjikan.

Menurut Pasal 18 Ayat (1) Pelaku usaha dalam menawarkan barang dan/atau jasa yang ditujukan untuk

25 Undang-undang No. 8 Tahun 1999, Op.Cit., Pasal 19 ayat 3 .

${ }^{26}$ Ibid, Pasal 20.

${ }^{27}$ Ibid, Pasal 27 diperdagangkan dilarang membuat atau mencantunkan klausula baku pada setiap dokumen/atau perjanjian apabila : ${ }^{28}$

a. menyatakan pengalihan tanggung jawab pelaku usaha;

b. menyatakan bahwa pelaku usaha berhak menolak penyerahan kembali barang yang dibeli konsumen;

c. menyatakan bahwa pelaku usaha berhak menolak penyerahan kembali uang yang dibayarkan atas barang dan/atau jasa yang dibeli oleh konsumen;

d. menyatakan pemberian kuasa dari konsumen kepada pelaku usaha baik secara langsung untuk melakukan segala tindakan sepihak yang berkaitan dengan barang yang dbeli oleh konsumen secara angsuran;

e. mengatur perihal pembuktian atas hilangnya kegunaan barang atau pemanfaatan jasa yang dibeli konsumen;

f. memberi hak kepada pelaku usaha untuk mengurangi manfaat jasa atau mengurangi harta kekayaan konsumen yang menjadi objek jual beli jasa;

g. menyatakan tunduknya konsumen kepada peraturan yang berupa aturan baru, tambahan, lanjutan dan/atau pengubahan lanjutan yang dibuat sepihak oleh pelaku usaha dalam masa menyatakan konsumen memanfaatkan jasa yang dibelinya;

h. bahwa konsumen memberi kuasa kepada pelaku usaha untuk pembebanan hak jaminan terhadap 
barang yang dibeli oleh konsumen secara angsuran.

Selanjutnya dalam Pasal 18 ayat (2) dijelaskan bahwa pelaku usaha dilarang mencantumkan klausula baku yang letak dan bentuknya sulit terlihat atau tidak dapat dibaca secara jelas, atau yang pengungkapannya sulit dimengerti. Sebagai konsekuensi atas pelanggaran terhadap ketentuan Pasal 18 Ayat (1) dan (2) tersebut, Pasal 18 Ayat (3) UUPK menyatakan batal demi hukum dalam arti klausula baku tersebut dianggap tidak pernah ada dan tidak mengikat para pihak. Sehingga atas kebatalan tersebut maka dalam Pasal 18 Ayat (4) mewajibkan pelaku usaha untuk menyesuaikan klausula baku yang bertentangan dengan undang-undang ini. Bahwa pada prinsipnya UUPK tidak melarang pelaku usaha untuk membuat perjanjian standar yang memuat klausula baku atas suatu perjanjian, selama dan sepanjang perjanjian standar tersebut tidak mencantumkan ketentuan sebagaimana dilarang dalam pasal 18 angka (1) serta tidak berbentuk sebagaimana dilarang dalam pasal 18 angka (2) dalam undang -undang ini. ${ }^{29}$

Badan perlindungan konsumen:

1. Berkedudukan di ibu kota negara Republik Indonesia dan bertanggung jawab kepada Presiden.

2. Badan Perlindungan Konsumen Nasional mempunyai fungsi memberikan saran dan pertimbangan kepada pemerintah dalam upaya mengembangkan

${ }^{29}$ Ibid, Pasal 32-34 perlindungan konsumen di Indonesia.

3. Perlindungan Konsumen Nasional mempunyai tugas:

a. memberikan saran dan rekomendasi kepada pemerintah dalam rangka penyusunan kebijaksanaan di bidang perlindungan konsumen;

b. melakukan penelitian dan pengkajian terhadap peraturan perundang-undangan yang berlaku di bidang perlindungan konsumen;

c. melakukan penelitian terhadap barang dan/atau jasa yang menyangkut keselamatan konsumen;

d. mendorong berkembangnya lembaga perlindungan konsumen swadaya masyarakat;

e. menyebarluaskan informasi melalui media mengenai perlindungan konsumen dan memasyarakatkan sikap keberpihakan kepada konsumen;

f. menerima pengaduan tentang perlindungan konsumen dari masyarakat, lembaga perlindungan konsumen swadaya masyarakat, atau pelaku usaha;

g. melakukan survei yang menyangkut kebutuhan konsumen.

\section{Penyelesaian sengketa konsumen}

Pada dasarnya tidak seorangpun menghendaki terjadinya sengketa dengan orang lain, tidak terkecuali dalam kegiatan bisnis khususnya antara produsen dan konsumen. Apabila hal ini terjadi, maka mengakibatkan kerugian-kerugian 
kepada pihak-pihak yang bersengketa baik yang berada pada posisi yang benar maupun pada posisi yang salah. Walaupun demikian, sengketa diantara mereka kadang-kadang tidak dapat dihindari. Hal ini disebabkan karena adanya kesalahpahaman, pelanggaran undang-undang, ingkar janji, kepentingan yang berlawanan, kerugian salah satu pihak.

Menurut $\begin{array}{r}\text { Shidarta } \\ \text { adalah }\end{array} \begin{array}{r}\text { sengketa } \\ \text { sonsumeta }\end{array}$
berkenaan dengan pelanggaran
hak-hak konsumen. $\begin{array}{r}\text { Lingkupnya } \\ \text { mencakup semua segi hukum baik }\end{array}$
keperdataan, pidana maupun tata
usaha negara. Oleh karena itu tidak
digunakan istilah "sengketa
transaksi konsumen" karena yang
terakhir terkesan lebih sempit, yang
hanya mencakup aspek hukum
keperdataan saja. ${ }^{30}$

$\begin{array}{lr}\begin{array}{l}\text { Sedangkan Az. } \\ \text { mengemukakan, }\end{array} & \begin{array}{r}\text { Nasution } \\ \text { sengketa }\end{array} \\ \text { konsumen adalah } & \begin{array}{r}\text { setiap } \\ \text { perselisihan antara }\end{array} \\ \text { konsumen } \\ \text { dengan penyedia } & \text { produk } \\ \text { konsumen (barang dan/atau jasa } \\ \text { konsumen) dalam hubungan } \\ \text { hukum satu sama lain, menegnai } \\ \text { produk konsumen tertentu. }{ }^{31}\end{array}$

Sengketa ini dapat menyangkut pemberian sesuatu, berbuat sesuatu, atau tidak berbuat sesuatu sebagaimana diatur dalam Pasal 1233 jo $1234 \mathrm{KUH}$ Perdata atau dapat pula berbagai kombinasi dari

${ }^{30}$ Shidarta, Hukum Perlindungan Konsumen Indonesia, Jakarta: PT.Gramedia Widiasarana Indonesia, 2004, hal. 165.

${ }^{31}$ Az. Nasution, Op.Cit., hal. 178. prestasi tersebut. Objek sengketa konsumen dalam hal ini dibatasi hanya menyangkut produk konsumen yaitu barang atau jasa yang pada umumnya digunakan untuk keperluan rumah tangganya dan tidak untuk tujuan komersial.

Pasal 23 UUPK menyebutkan bahwa apabila pelaku usaha pabrikan dan/atau pelaku usaha distributor menolak dan/atau tidak memberi tanggapan dan/atau tidak memenuhi ganti rugi atas tuntutan konsumen, maka konsumen diberikan hak untuk menggugat pelaku usaha dan menyelesaikan perselisihan yang timbul melalui Badan Penyelesaian Sengketa Konsumen (BPSK) atau dengan cara mengajukan gugatan kepada peradilan di tempat kedudukan konsumen tersebut. Jadi dalam upaya penyelesaian sengketa konsumen menurut UUPK terdapat dua pilihan, yaitu: Melalui lembaga yang bertugas menyelesaikan sengketa antara konsumen dan pelaku usaha (dalam hal ini BPSK), atau Melalui peradilan yang berada di lingkungan peradilan umum

\section{Pentingnya Perlindungan Konsumen di Indonesia}

Setiap orang pada suatu waktu dalam posisi tunggal/sendiri maupun berkelompok bersama orang lain, dalam keadaan apapun pasti menjadi konsumen untuk suatu produk barang atau jasa tertentu. Dalam hal ini timbul hubungan hukum bagi konsumen dan pelaku usaha, hubungan tersebut menimbulkan akibat hukum terhadap semua pihak 
atau kepada pihak-pihak tertentu. Dalam menjalankan hubungan tersebut, kadang timbul masalah, untuk itu perlu diatur perlindungan konsumen berdasarkan undangundang menyangkut, antara lain: mutu barang, cara prosedur produksi, syarat kesehatan, syarat pengemasan, syarat lingkungan, dan sebagainya. Sehingga tujuan dari hukum perlindungan konsumen dapat tercapai, yaitu: secara langsung dapat meningkatkan martabat dan kesadaran konsumen, dan secara tidak langsung, hukum ini juga akan mendorong produsen untuk melakukan usaha dengan penuh tanggung jawab.

Menurut Johanes Gunawan, perlindungan hukum terhadap konsumen dapat dilakukan pada saat sebelum terjadinya transaksi (no conflict/pre purchase) dan/atau pada saat setelah terjadinya transaksi (conflict/post purchase). ${ }^{32}$ Perlindungan hukum terhadap konsumen yang dapat dilakukan pada saat sebelum terjadinya transaksi (no conflict/pre purchase) dapat dilakukan dengan cara antara lain:

1. Legislation, yaitu perlindungan hukum terhadap konsumen yang dilakukan pada saat sebelum terjadinya transaksi dengan memberikan perlindungan kepada konsumen melalui peraturan perundang-undangan yang telah dibuat. Sehingga dengan adanya peraturan perundang tersebut diharapkan konsumen memperoleh

32 Johanes Gunawan, Hukum Perlindungan Konsumen, Bandung: Universitas Katolik Parahyangan, 1999, hal. 3. perlindungan sebelum terjadinya transaksi, karena telah ada batasanbatasan dan ketentuan yang mengatur transaksi antara konsumen dan pelaku usaha.

2. Voluntary Self Regulation, yaitu perlindungan hukum terhadap konsumen yang dilakukan pada saat sebelum terjadinya transaksi, dimana dengan cara ini pelaku usaha diharapkan secara sukarela membuat peraturan bagi dirinya sendiri agar lebih berhati-hati dan waspada dalam menjalankan usahanya. ${ }^{33}$

Sedangkan untuk perlindungan hukum terhadap konsumen pada saat setelah terjadinya transaksi (conflict/post purchase) dapat dilakukan melalui jalur Pengadilan Negeri (PN) atau diluar Pengadilan oleh Badan Penyelesaian Sengketa Konsumen (BPSK) berdasarkan pilihan para pihak yang bersengketa. Perlindungan hukum terhadap konsumen diperlukan karena konsumen dalam posisi yang lemah. Perbedaan kepentingan antara pelaku usaha dan konsumen menyebabkan gangguan fisik, jiwa atau harta konsumen dan tidak diperolehnya keuntungan optimal dari penggunaan barang dan/atau jasa tersebut dan miskinnya hukum yang melindungi kepentingan konsumen. Dengan adanya perlindungan hukum bagi konsumen, diharapkan dapat memberikan kedudukan hukum yang seimbang antara konsumen dengan pelaku usaha. Hal tersebut cukup beralasan karena selama ini kedudukan konsumen yang lemah jika dibandingkan dengan pelaku usaha.

\footnotetext{
${ }^{33}$ Ibid, hal. 4.
} 
Hukum perlindungan konsumen sangat dibutuhkan di Indonesia, antara lain: bahwa pembangunan nasional bertujuan untuk mewujudkan suatu masyarakat adil dan makmur yang merata materiil dan spiritual dalam era demokrasi ekonomi berdasarkan Pancasila dan UndangUndang Dasar 1945; bahwa pembangunan perekonomian nasional pada era globalisasi harus dapat mendukung tumbuhnya dunia usaha sehingga mampu menghasilkan beraneka barang dan/jasa yang memiliki kandungan teknologi yang dapat meningkatkan kesejahteraan masyarakat banyak dan sekaligus mendapatkan kepastian atas barang dan/jasa yang diperoleh dari perdagangan tanpa mengakibatkan kerugian konsumen; bahwa semakin terbukanya pasar nasional sebagai akibat dari proses globalisasi ekonomi harus tetap menjamin peningkatan kesejahteraan masyarakat serta kepastian atas mutu, jumlah dan keamanan barang dan/atau jasa yang diperolehnya di pasar; bahwa untuk meningkatkan harkat dan martabat konsumen perlu meningkatkan kesadaran, pengetahuan, kepedulian, kemampuan dan kemandirian konsumen untuk melindungi dirinya serta menumbuhkembangkan sikap perilaku usaha yang bertanggung jawab.

Tujuan perlindungan konsumen menurut pasal 3 UUPK adalah: ${ }^{34}$

a. meningkatkan kesadaran, kemampuan, dan kemandirian konsumen untuk melindungi diri;

${ }^{34}$ Undang-undang No 8 Tahun 1999, Op.Cit., Pasal 3 b. mengangkat harkat dan martabat konsumen dengan cara menghindarkannya dari akses negatif pemakaian barang atau jasa;

c. meningkatkan pemberdayaan konsumen dalam memilih, menentukan dan menuntut hakhaknya sebagai konsumen;

d. menciptakan perlindungan konsumen yang mengandung unsur kepastian hukum dan keterbukaan informasi serta akses untuk mendapatkan informasi;

e. kesadaran pelaku usaha mengenai pentingnya perlindungan konsumen sehingga tumbuh sikap yang jujur dan bertanggung jawab dalam berusaha.

f. meningkatkan kualitas barang dan/atau jasa yang menjamin kelangsungan usaha produksi barang dan/atau jasa, kesehatan, kenyamanan, keamanan, dan keselamatan konsumen.

Secara umum dikenal ada empat hak dasar konsumen yang harus dilindungi, yaitu: "hak untuk mendapatkan keamanan (the right to safety), hak untuk mendapat informasi (the right to be informed), hak untuk memilih (the right to choose) dan akhirnya hak untuk didengar (the right to be heard)". ${ }^{35}$

\section{Kendala / Hambatan Dalam Pelaksanaan Perlindungan Konsumen di Indonesia}

Indonesia telah telah meratifikasi Agreement Establishing the World Trade Organization (Persetujuan Pembentukan Organisasi Perdagangan

\footnotetext{
${ }^{35}$ Shidarta, Op.Cit., hal. 16.
} 
Dunia) yang mencakup Agreement on Trade Related Aspects of Intellectual Property Rights (Persetujuan TRIPs) dan telah membentuk Undang-undang No.8 Tahun 1999 Tentang Perlindungan Konsumen. Sebagai konsekuensinya tentu berkomitmen dalam pelaksanaanya akan selalu memperhatikan perlindungan konsumen. Namun demikian dalam prakteknya perlindungan hukum terhadap konsumen masih menimbulkan berbagai permasalahan. Permasalahan tersebut dipengaruhi berbagai faktor, antara lain: yang berkaitan dengan struktur hukum, substansi hukum, budaya hukum dan aparatur birokrasi. Secara garis besar kendala atau hambatan yang dihadapi dalam pelaksanaan UUPK adalah: karena tingkat kesadaran konsumen akan haknya masih rendah; rendahnya pendidikan konsumen; belum ada pihak yang menyentuh bagaimana mempersiapkan konsumen Indonesia menghadapi pasar bebas; masih lemahnya pengawasan dibidang standardisasi mutu barang; lemahnya produk perundang-undangan; persepsi pelaku usaha yang keliru dengan perlindungan konsumen akan menimbulkan kerugian.

Untuk mengatasi permasalahanpermasalah tersebut, maka perlu dicarikan solusi, antara lain prasyaratprasyarat apa yang harus dipenuhi agar era perdagangan bebas bagi konsumen di Indonesia menjadi anugerah, justru bukan sebaliknya menjadi musibah. Langkah yang ditempuh, antara lain sebagai berikut :

1. Perdagangan didasarkan pada prinsip pelaku usaha dan konsumen

sama-sama membutuhkan, dan saling ketergantungan satu sama lain baik dalam waktu yang singkat maupun waktu yang lama untuk itu dibutuhkan perlindungan hukum yang seimbang.

2. UUPK ini dirumuskan dengan mengacu pada filosofi pembangunan nasional, yaitu membangun manusia Indonesia seutuhnya yang berlandaskan pada falsafah kenegaraan Republik Indonesia yaitu Pancasila dan UUD 1945.

3. Melakukan revisi terhadap UUPK yang ada dengan senantiasa memperhatikan kepentingan pelaku usaha dan konsumen secara seimbang, mengakomodir kepentingan nasional dan internasional. Piranti hukum yang melindungi konsumen tidak dimaksudkan untuk mematikan usaha para pelaku usaha, tetapi justru sebaliknya perlindungan konsumen dapat mendorong iklim berusaha yang sehat yang mendorong lahirnya perusahaan yang tangguh dalam menghadapi persaingan melalui penyediaan barang dan/atau jasa yang berkualitas.

4. Aparat penegak hukum harus benar-benar serius dalam mengawasi, memproses dan menyelesaikan setiap pelanggaran yang terjadi dengan memberikan hukuman/sanksi yang tegas dan setimpal agar menimbulkan efek jera bagi yang melakukan pelanggaran.

5. Hukum yang dibentuk adalah hukum yang responsif, sehingga dapat mengakomodasi masalahmasalah yang timbul, mmasukan- 
masukan masyarakat yang berkaitan dengan perlindungan hukum dan kepastian lingkup perlindungan konsumen.

\section{KESIMPULAN DAN SARAN}

\section{Kesimpulan}

1. Pentingnya perlindungan hukum terhadap konsumen diatur dalam undang-undang adalah untuk mencegah timbulnya masalah dikemudian hari karena setiap orang baik sendiri maupun secara bersama-sama dalam keadaan apapun pasti menjadi konsumen untuk suatu produk barang atau jasa tertentu. Secara umum ada empat hak dasar konsumen yang harus dilindungi, yaitu: hak untuk mendapatkan keamanan (the right to safety), hak untuk mendapat informasi (the right to be informed); hak untuk memilih (the right to choose) dan akhirnya hak untuk didengar (the right to be heard). Perlindungan hukum terhadap konsumen dapat dilakukan pada saat sebelum terjadinya transaksi (no conflict/pre purchase) dan/atau pada saat setelah terjadinya transaksi (conflict/post purchase). Di Indonesia perlindungan konsumen dibutuhkan antara lain: Bahwa pembangunan nasional bertujuan untuk mewujudkan suatu masyarakat adil dan makmur yang merata materiil dan spiritual dalam era demokrasi ekonomi berdasarkan Pancasila dan UUD 1945; bahwa pembangunan perekonomian nasional pada era globalisasi harus dapat mendukung tumbuhnya dunia usaha sehingga mampu menghasilkan beraneka barang dan/jasa yang memiliki kandungan teknologi yang dapat meningkatkan kesejahteraan masyarakat banyak dan sekaligus mendapatkan kepastian atas barang dan/jasa yang diperoleh dari perdagangan tanpa mengakibatkan kerugian konsumen; bahwa semakin terbukanya pasar nasional sebagai akibat dari proses globalisasi ekonomi harus tetap menjamin peningkatan kesejahteraan masyarakat serta kepastian atas mutu, jumlah dan keamanan barang dan/atau jasa yang diperolehnya di pasar; bahwa untuk meningkatkan harkat dan martabat konsumen perlu meningkatkan kesadaran, pengetahuan, kepedulian, kemampuan dan kemandirian konsumen untuk melindungi dirinya serta menumbuhkembangkan sikap perilaku usaha yang bertanggung jawab.Tujuan perlindungan konsumen menurut pasal 3 UUPK adalah: meningkatkan kesadaran, kemampuan, dan kemandirian konsumen untuk melindungi diri; mengangkat harkat dan martabat konsumen dengan cara menghindarkannya dari akses negatif pemakaian barang atau jasa; meningkatkan pemberdayaan konsumen dalam memilih, menentukan dan menuntut hak- haknya sebagai konsumen; menciptakan perlindungan konsumen yang mengandung unsur kepastian hukum dan keterbukaan informasi serta akses untuk mendapatkan informasi; menumbuhkan kesadaran pelaku usaha mengenai pentingnya perlindungan konsumen sehingga tumbuh sikap yang jujur dan bertanggung jawab dalam berusaha; meningkatkan kualitas barang dan/atau jasa yang menjamin kelangsungan usaha produksi barang dan/atau jasa, kesehatan, kenyamanan, keamanan, dan keselamatan konsumen.

2. Dalam prakteknya perlindungan hukum terhadap konsumen masih 
menimbulkan berbagai permasalahan. Permasalahan tersebut dipengaruhi berbagai faktor, antara lain: yang berkaitan dengan struktur hukum, substansi hukum, budaya hukum dan aparatur birokrasi. Secara garis besar kendala atau hambatan yang dihadapi dalam pelaksanaan UUPK adalah: karena tingkat kesadaran konsumen akan haknya masih rendah; rendahnya pendidikan konsumen; belum ada pihak yang menyentuh bagaimana mempersiapkan konsumen Indonesia menghadapi pasar bebas; masih lemahnya pengawasan dibidang standardisasi mutu barang; lemahnya produk perundang-undangan; persepsi pelaku usaha yang keliru dengan perlindungan konsumen akan menimbulkan kerugian.

\section{Saran}

1. Sesegera mungkin dilakukan revisi terhadap UUPK yang ada, dimana didalamnya diatur keseimbangan antara kepentingan pelaku usaha dan konsumen dengan tetap memperhatikan kepentingan nasional dan juga harus mengakomodir kepentingan internasional.

2. Hukum yang akan dibentuk adalah hukum yang responsif, yang dapat mengakomodir masalah-masalah yang timbul, masukan-masukan masyarakat yang berkaitan dengan perlindungan hukum konsumen dan kepastian lingkup perlindungan konsumen

3. Aparat penegak hukum harus benarbenar serius dalam mengawasi, memproses dan menyelesaikan setiap pelanggaran yang terjadi dengan memberikan hukuman/sanksi yang tegas dan setimpal agar menimbulkan efek jera bagi yang melakukan pelanggaran.

\section{DAFTAR PUSTAKA}

\section{A. Buku}

Celina Tri Siwi Kristiyanti, Hukum Perlindungan Konsumen, Jakarta: Sinar Grafika, 2008.

Gunawan Widjaja dan Ahmad Yani, Hukum tentangPerlindungan Konsumen, Jakara: PT Gramedia Pustaka Utama, 2001.

Johanes Gunawan, Hukum Perlindungan Konsumen,Bandung: Universitas Katolik Parahyangan, 1999.

Mariam Darus Badrulzaman, Perlindungan Terhadap Konsumen Dilihat Dari Sudut Perjanjian Baku (Standar), dalam BPHN, Simposium Aspek -Aspek Hukum Perlindungan Konsumen, Bandung: Binacipta, 1986.

Nasution, Az, Konsumen dan Hukum, Jakarta: Pustaka Sinar Harapan, 1995.

Shidarta, Hukum Perlindungan Konsumen, Jakarta: PT Grasindo, 2000.

Hukum Perlindungan Konsumen Indonesia, Jakarta: PT.Gramedia Widiasarana Indonesia, 2004.

Zoemrotin K.Susilo, Penyambung Lidah Konsumen, Jakarta: Puspa Swara, 1996.

\section{B. Peraturan Perundang-undangan}

Undang-undang No.8 Tahun 1999 tentang Perlindungan Konsumen. 